\title{
Dairy Wastewater Treatment by Cyanobacteria for Removal of Nutrients with Extraction of High Value Compounds from Biomass
}

\author{
Jayesh H. Kabariya and Vimal M. Ramani* \\ Department of Dairy Microbiology, College of Dairy Science, Kamdhenu University, \\ Amreli-365601, Gujarat, India \\ *Corresponding author
}

\section{A B S T R A C T}

\begin{tabular}{|l|}
\hline Ke y w o r d s \\
$\begin{array}{l}\text { Dairy wastewater } \\
\text { treatment, Cyanobacteria, } \\
\text { C-phycocyanin, } \\
\text { Phycoerythrin and Lipid } \\
\text { content }\end{array}$ \\
\hline Article Info \\
\hline $\begin{array}{l}\text { Accepted: } \\
\text { 12 March 2018 } \\
\text { Available Online: } \\
\text { 10 April 2018 }\end{array}$ \\
\hline \hline
\end{tabular}

\section{Keywords}

C-phycocyanin,

content

Article Info

Accepted:

Available Online:

10 April 2018
Dairy industry is one of the leading food industries in India. Dairy is one of the major industries causing water pollution with its large water consumption approximately 50 $\mathrm{m}^{3}$ wastewater daily with considerable concentration of organic and inorganic matter. In present study cyanobacterial species were isolated from dairy industries wastewater and explored for removal of nutrients from dairy wastewater simultaneously biomass produced again used for extraction of high value compounds. The overall percentage of nitrogen reduction was $75.22 \%, 81.69 \%$ and $76.56 \%$ by Oscillatoria, Phormidium species and its consortium, respectively, while phosphate reduction percentage was $86 \%, 94 \%$ and $90.66 \%$ by Oscillatoria, Phormidium species and its consortium, respectively after 18 days. In case of high value compounds extraction from Oscillatoria, Phormidium species and its consortium, Oscillatoria species produced highest amount of C-phycocyanin 0.133 $\mathrm{mg} / \mathrm{L}$ and Phycoerythrin $0.221 \mathrm{mg} / \mathrm{L}$ compare to Phormidium species and its consortium. The lipid content from Oscillatoria species was about $175.02 \mathrm{mg} / \mathrm{l}^{-1}$ which can be used for biofuel production.

\section{Introduction}

Dairy industry is one of the major food industries in India. India ranks first for the maximum milk producing nation. Water pollution from dairy wastewater has been major problem of environmental concern in countries around the world. This industry generates large volume of wastewater with its high nutrient characteristics, that's why dairy industrial wastewater is more polluting. In dairy industries approximately two to three times greater amount of wastewater generates for the processing of each liter of milk
(Vourch et al., 2008). The dairy industry on an average has been reported to generate three to five liters of waste water per liter of the milk processed. It is estimated that about $2 \%$ of the total milk processed is wasted into drains. Due to the high pollution load of dairy wastewater some of the milk-processing industries discharging untreated/partially treated wastewater which can cause serious environmental problems like water and soil pollution.

Dairy industries generates approximately 50 $\mathrm{m}^{3}$ wastewater daily with considerable 
concentration of organic matter (fat, protein and carbohydrates) and nutrients mainly (nitrogen and phosphorous) originating from the milk and the milk products. High amount of organic and inorganic compound in dairy wastewater can produce excess growth of algae, eutrophication and also effect on biodiversity that cause decreased water quality level that may affect human and animal health.

In recent years, environmentalists and government are looking for efficient, economic and long lasting solutions for dairy wastewater treatment and recycling. The traditional method of dairy wastewater treatment is available but it is unavoidably, costly, time consuming process and it cannot be affordable in all industries especially in developing countries like India. In dairy wastewater plant (ETP) involves high energy cost by mechanical aeration to provide oxygen to microorganism to degrade the organic matter in wastewater. Dairy wastewater treatment process produced large amount of sludge and it must be remove. The removal of this sludge is usually the more cost component in process of dairy wastewater treatment. Roughly one $\mathrm{kg}$ of BOD removed in an activated sludge process requires one $\mathrm{kWh}$ of electricity for aeration, which produces one $\mathrm{kg}$ of fossil $\mathrm{CO}_{2}$ from power generation (Oswald et al., 2003). By contrast, one $\mathrm{kg}$ of BOD removed by photosynthetic oxygenation requires no energy inputs and produces enough algal biomass to generate methane that can produce one $\mathrm{kWh}$ of electric power (Blok et al., 1985).

Hence in recent years, the importance of biological treatment systems has attracted the attention of investigators in all over the world and it help to develop the efficient and low cost dairy wastewater treatment systems. Lowcost dairy wastewater treatment methods are prime need for the developing countries. Dairy wastewater contains sufficient nutrients for cyanobacterial growth. The role of cyanobacteria in the removal of various kinds of organic, inorganic and other related substances has been studied by several workers during the last several years. Nutrient removal in particular nitrogen and phosphorus from dairy wastewater is a growing regulatory need and the use of cyanobacteria cultivation could create a unique combination between dairy wastewater treatment and from produced cyanobacterial biomass extract high value compounds.

The present study aims to evolve effective and economic biological treatment method for dairy wastewater using cyanobacteria and to produce its biomass for their economical applications. In this study we have isolates the cyanobacteria from dairy wastewater plant and dairy industry which having different product production range like, packaged milk, buttermilk, butter and ghee. In next step isolated cyanobacteria were used for dairy wastewater treatment by removal of nutrients and separate the generated biomass for the extraction of high value compounds. From such cyanobacterial biomass, some of the important high value compounds such as biofuel, antioxidant compounds, pigments, neutraceuticals like omega 3, carotenoids, astaxanthin, single cell protein (Oscillatoria). The antioxidant compounds such as phycobiliproteins, c-phycocyanin (C-PC) and phycoerythrin $(\mathrm{PE})$ have high economic value like, $\$ 110-500 / \mathrm{mg}, \quad \$ 1050 / \mathrm{mg}$ and $\$ 30$ 724/mg, respectively (Sara et al., 2015).

\section{Materials and Methods}

\section{Collection of dairy wastewater sample}

Treated and untreated dairy wastewater sample collection was carried out from area of Bhavanagar district, Gujarat. The dairy industry having different product production range like packaged milk, buttermilk, butter 
and ghee. Which also have slight different environmental condition and dairy product range compare to other region of Gujarat and dairy industry. So, chance to availability of diverse cyanobacterial species is high. The dairy wastewater sample collection was taken from the wastewater entry point (untreatedprimarily tank) and at final discharge tank (treated-secondary clarifier) of wastewater treatment plant. The sample collection was carried out in sterilized glass and plastic sampling bottle and after collection of sample it reach to laboratory within $4-6 \mathrm{~h}$ at $4{ }^{\circ} \mathrm{C}$.

\section{Isolation of cyanobacteria from dairy wastewater}

Isolation of cyanobacteria from dairy wastewater sample was carried out using modified method of Ferris and Hirsch 1991. First shake the dairy wastewater sample and allow to sediment suspended particle, repeat this process for three times to removed suspended particle and then add $100 \mathrm{ml}$ sterile distilled water and filtered it by filter. Then filter were place on BG-11 (Blue Green-11, Hi-Media, India) medium containing petri plate. The composition of BG-11 medium are as follow in $\mathrm{gm} / \mathrm{L}$; Sodium nitrate-1.500, Dipotassium hydrogen phosphate-0.0314, Magnesium sulphate-0.036, Calcium chloride dehydrate-0.0367, Sodium carbonate-0.020, Disodium magnesium EDTA-0.001, Citric acid-0.0056, Ferric ammonium citrate-0.006 and final $\mathrm{pH} 7.1 \pm 0.2$ after sterilization. Incubate petri plate with filter paper for 15 days under continuous lighting (2000 lux) 14:10 h light: dark system at $28 \pm 2{ }^{\circ} \mathrm{C}$. After incubation period different species of cyanobacteria were grow in medium. Aseptically each species were picked and subcultured in 500 mL BG-11 medium for growth of organism and incubated under same condition. Isolated cynobacterial species was purified then identified and check the capacity of nutrient removal from dairy wastewater and extract the high value compound from produced biomass.

\section{Purification of cyanobacterial culture}

Purification of cyanobacteria was carried out according to Elango et al., (2008). $100 \mathrm{~mL}$ of tap water and distilled water was taken and checked the $\mathrm{pH}$ separately before and after sterilization. $1 \mathrm{~mL}$ of cyanobacterial culture as an inoculum was added into the sterilized water which used as a medium for the removal of bacteria, planktons and other contaminations. Then it was incubated at $27 \pm$ $2{ }^{\circ} \mathrm{C}$ with light intensity of 2000 lux in $14 / 10 \mathrm{~h}$ light and dark cycle. After 5 days of incubation the cyanobacterial culture was examined under microscope for contamination. Then remove the contaminating dead cells which adsorbed on cyanobacterial species by washing the culture with sterilized double distilled water. Subculturing was carried out in the same medium which helps to obtain good effective results. The purity of the culture was checked under light microscope.

\section{Morphological identification of cyanobacteria}

Identification of cyanobacteria was carried out using a trinocular microscope (Nikon Eclipse$\mathrm{Ni}$ ) with NikonDS-Fi2 camera. Identification was carried out up to genera level by compare with Algae Identification lab guide Agriculture and Agri-Food Canada AgriEnvironment Services (Nancy et al., 2011).

\section{Physico-chemical characterization of dairy wastewater}

Physico-chemical characterization of dairy wastewater was carried out by using standard method of Lenore et al., 1998 and Trivedy et al., 1984. The parameters includes, $\mathrm{pH}$, temperature, colour, dissolve oxygen(DO), 
biochemical oxygen demand (BOD), chemical oxygen demand (COD), chloride, sulphate, nitrate and phosphorus were measured according to standard method. These methods were check present amount of nutrient content before and after inoculation of cyanobacterial culture into dairy wastewater.

Inoculation of cyanobacterial culture into dairy wastewater

Oscillatoria species, Phormidium species and its consortium were used as inoculum for dairy wastewater treatment. $10 \%$ cyanobacterial cultures were used as an inoculum for growth in Erlenmeyer flask (500 $\mathrm{ml}$ ) containing $250 \mathrm{ml}$ of untreated and treated dairy wastewater. The culture was incubated at $27{ }^{\circ} \mathrm{C} \pm 3{ }^{\circ} \mathrm{C}$ temperature for 18 days and measured physico-chemical analysis at interval of every 6 days (Woertz et al., 2005).

Separation of cyanobacterial biomass for dairy wastewater

Take the $250 \mathrm{ml}$ of cyanobacterial treated dairy wastewater centrifuge it at $10,000 \mathrm{rpm}$ for 10 minutes, take the supernatant solution for physico-chemical analysis and cyanobacterial biomass which settle down as a pellet. Use this biomass for further extraction of high value compounds.

\section{Extraction of phycobiliproteins from cyanobacterial biomass}

The extraction of phycobiliproteins from cyanobacterial biomass of oscillatoria species, phormidium species and its consortium were carried out by freezing and thawing method (Patel et al., 2005). Cyanobacterial culture was rinsed two times with double distilled water and lyophilized (ANM FD-307K) it with sucrose which was used as a cryoprotectant. $1 \mathrm{gm}$ of lyophilized biomass was added into $100 \mathrm{~mL}$ of $0.1 \mathrm{M}$ sodium phosphate buffer ( $\mathrm{pH}$ 7.0) which contain 1 $\mathrm{mM}$ sodium azide. Then this solution was sonicated (LABMAN PRO-SONICATOR500) for 60 to 80 seconds and freeze it at -20 ${ }^{\circ} \mathrm{C}$ then it was thawing at room temperature in the dark condition. This procedure was repeated for three time. The mixture was centrifuge at $10,000 \mathrm{rpm}$ for 30 minutes at $4^{\circ} \mathrm{C}$ and collect the clear supernatant containing phycobiliproteins.

\section{Estimation of phycobiliproteins}

The amount of phycobiliproteins present in clear supernatant was measure by UV-Visible spectrophotometer (ELICO SL-244) at wavelengths 565, 620 and $650 \mathrm{~nm}$ for the calculating the concentration of Cphycocyanin and phycoerythrin by using following equations:

Phycoerythrin $(P E)(\mathrm{mg} / \mathrm{ml})=\left(0.123 A_{565}-\right.$ $\left.0.068 A_{620}\right)+0.015 A_{650}$

C-Phycocyanin $(C-P C)(\mathrm{mg} / \mathrm{ml})=\left(0.162 A_{620}\right.$ $\left.-0.001 A_{565}\right)-0.098 A_{650}$

\section{Extraction of lipid from cyanobacterial biomass}

The cyanobacterial biomass of oscillatoria species, phormidium species and its consortium were separated by centrifuge at $10000 \mathrm{rpm}$ for 10 minute. Supernatant was discarded and freeze the biomass at $-20{ }^{\circ} \mathrm{C}$ for overnight and then it was freeze dried by vacuum freeze dryer (ANM FD-307K). The next step of the experiment was cell disruption by ultrasound system. Take $1 \mathrm{gm}$ of freeze dried cyanobacterial biomass in $50 \mathrm{ml}$ of double distilled water and mix it vigorously. Then this mixture was sonicate (LABMAN PRO-SONICATOR-500) at 45 amplitude for five minutes. After this, mixture was used for the extraction of lipid (Bligh and Dyer 1959). The sonicated mixture was transferred into 
separating funnel and mixture of chloroform: methanol $(2: 1 \mathrm{v} / \mathrm{v})$ was added and mixed vigorously for 10-15 minutes. Top milk layer was removed from separating funnel and left it for overnight for the solvent evaporations. Then the weight of extracted crude lipid from cyanobacterial biomass was measured.

\section{Results and Discussion}

\section{Collection and isolation of cyanobacteria from dairy wastewater sample}

Collection of dairy wastewater sample was carried out from dairy industries around the Bhavnagar district, Saurashtra, Gujarat.

Four dairy wastewater samples were taken from dairy industry, two sample of untreated wastewater and two sample of treated dairy wastewater. Total two cyanobacterial species were isolated using BG11 medium from dairy industries wastewater around the Bhavnagar district. These two species were used to preliminary study of dairy wastewater treatment by cyanobacteria and extraction of high value compounds from generated cyanobacterial biomass.

\section{Morphological identification cyanobacteria}

The morphological identification was carried out by using trinocular microscope (Nikon Eclipse-Ni) with NikonDS-Fi2 camera attachment. Cyanobacterial species were identified on the basis of morphological characteristics upto genus level. The identified species of cyanobacteria was Oscillatoria and Phormidium genus which shows in Figure 1. The Oscillatoria species with filamentous, unseriated, unbranched trichomes and its name Oscillatoria on its oscillation movement and Phormidium was also has filamentous morphology with pointed one end tail while. In this study we have used two species of cynoabacteria, among two species one was oscillatoria and second one was phormium species. Pathade (2012) were reported the oscillatorial species present dominant genus in dairy wastewater. Our result is at par to this.

\section{Characteristics of dairy wastewater}

The analysis of physico-chemical characteristics of treated and untreated dairy wastewater were carried out for the comparison of traditional method with our cyanobacterial based dairy wastewater treatment and checked their efficiency. Various parameters such as $\mathrm{pH}$, temperature, color, DO, BOD, COD, phosphate, nitrogen, chloride and sulphate were measured which shows the difference between treated and untreated dairy wastewater shown in Table 1 . The enough amount of nutrient was present in untreated dairy wastewater to support cyanobacterial growth and it also considered as advantageous for pigment, lipid and other metabolites production. While in treated dairy effuent the nutrient level was quit less compare to untreated dairy wastewater. The treated dairy wastewater nutrient data was used to compare the efficiency of reduced amount of nutrient by traditional and cyanobacteria based dairy wastewater treatment. Munawar (1970a, b) suggested that nutrient rich dairy wastewater especially calcium, nitrogen, phosphorus and other nutrient enhance the flourishing growth of blue green algae. Uslu et al., (2011) found that the amount of nitrogen was critical factor for the lipid and other metabolites production in cyanobacterial cell.

\section{Nutrient removal from dairy wastewater treatment by cyanobacterial species and its consortium}

The higher amount of nutrients such as nitrogen and phosphate were present in dairy wastewater. 
Table.1 Physico-chemical parameters of diary wastewaters

\begin{tabular}{|c|l|c|c|}
\hline Sr. No. & \multicolumn{1}{|c|}{ Parameters } & $\begin{array}{c}\text { Untreated Dairy } \\
\text { wastewater }(\mathbf{m g} / \mathbf{L})\end{array}$ & $\begin{array}{c}\text { Treated Dairy wastewater } \\
\text { (mg/L) }\end{array}$ \\
\hline $\mathbf{1}$ & Colour & off white & Transparent \\
\hline $\mathbf{2}$ & Temperature & 28.1 & 28.5 \\
\hline $\mathbf{3}$ & pH & 9.21 & 8.85 \\
\hline $\mathbf{4}$ & DO & 1.2 & 5.5 \\
\hline $\mathbf{5}$ & BOD & 166.11 & 10.08 \\
\hline $\mathbf{6}$ & COD & 96 & 16 \\
\hline $\mathbf{7}$ & Phosphate & 1.5 & 0.55 \\
\hline $\mathbf{8}$ & Nitrogen & 4.48 & 2.24 \\
\hline $\mathbf{9}$ & Chloride & 99.96 & 29.99 \\
\hline $\mathbf{1 0}$ & Sulphate & 19.0 & 2.90 \\
\hline
\end{tabular}

Table.2 Dairy wastewater treatment by cyanobacterial Oscillatorial species with reduction of nutrient present in dairy wastewater

\begin{tabular}{|c|c|c|c|c|c|c|}
\hline Sr. No. & Parameters & $\begin{array}{l}\text { Untreated dairy } \\
\text { wastewater } \\
\text { Zero Day }(\mathrm{mg} / \mathrm{L})\end{array}$ & $\begin{array}{c}6^{\text {th }} \text { Day } \\
\text { mg/L }\end{array}$ & $\begin{array}{c}12^{\text {th }} \text { Day } \\
\mathrm{mg} / \mathrm{L}\end{array}$ & $\begin{array}{c}18^{\text {th }} \text { Day } \\
\mathrm{mg} / \mathrm{L}\end{array}$ & $\begin{array}{c}\text { Overall } \\
\text { result after } \\
18 \text { days }(\%)\end{array}$ \\
\hline 1 & Colour & off white & slight off white & transparent & transparent & - \\
\hline 2 & Temperature $\left({ }^{\circ} \mathrm{C}\right)$ & 28.1 & 28.8 & 28.9 & 29.1 & - \\
\hline 3 & $\mathrm{pH}$ & 9.21 & 9.28 & 8.55 & 8.02 & 87.07 \\
\hline 4 & $\mathrm{DO}$ & 1.01 & 1.8 & 2.7 & 3.9 & +96.50 \\
\hline 5 & BOD & 166.11 & 20.03 & 12.5 & 3.49 & 97.89 \\
\hline 6 & COD & 96 & 20 & 17.6 & 7.2 & 92.50 \\
\hline 7 & Phosphate & 1.5 & 0.58 & 0.28 & 0.21 & 86.00 \\
\hline 8 & Nitrogen & 4.48 & 2.8 & 1.68 & 1.11 & 75.22 \\
\hline 9 & Chloride & 99.96 & 29.99 & 19.99 & 13.99 & 86.00 \\
\hline 10 & Sulphate & 19.05 & 8.02 & 5.02 & 3.52 & 81.52 \\
\hline 11 & Biomass $(\mathrm{gm} / 100 \mathrm{~mL})$ & 2.5 & 8.09 & 12.13 & 14.19 & +94.60 \\
\hline
\end{tabular}

Table.3 Dairy wastewater treatment by cyanobacterial Phormidium species with reduction of nutrient present in dairy wastewater

\begin{tabular}{|c|l|c|c|c|c|c|}
$\begin{array}{c}\text { Sr. } \\
\text { No. }\end{array}$ & \multicolumn{1}{|c|}{ Parameters } & $\begin{array}{c}\text { Untreated dairy } \\
\text { wastewater } \\
\text { Zero Day }(\mathbf{m g} / \mathbf{L})\end{array}$ & $\begin{array}{c}\mathbf{6}^{\text {th }} \mathbf{D a y} \\
\mathbf{m g} / \mathbf{L}\end{array}$ & $\begin{array}{c}\mathbf{1 2}^{\text {th }} \text { Day } \\
\mathbf{m g} / \mathbf{L}\end{array}$ & $\begin{array}{c}\mathbf{1 8} \text { th } \\
\mathbf{m g} / \mathbf{L}\end{array}$ & $\begin{array}{c}\text { Overall } \\
\text { result after } \\
\mathbf{1 8} \text { days } \mathbf{( \% )}\end{array}$ \\
\hline $\mathbf{1}$ & Colour & off white & slight off white & transparent & transparent & - \\
\hline $\mathbf{2}$ & Temperature $\left({ }^{\circ} \mathrm{C}\right)$ & 28.1 & 28.7 & 29.1 & 29.2 & - \\
\hline $\mathbf{3}$ & pH & 9.21 & 9.12 & 8.4 & 7.87 & 85.45 \\
\hline $\mathbf{4}$ & DO & 1.01 & 2.1 & 3.4 & 4.1 & +81.18 \\
\hline $\mathbf{5}$ & BOD & 166.11 & 26.6 & 14.51 & 3.11 & 98.12 \\
\hline $\mathbf{6}$ & COD & 96 & 24 & 13.6 & 5.6 & 94.16 \\
\hline $\mathbf{7}$ & Phosphate & 1.5 & 0.26 & 0.13 & 0.09 & 94.00 \\
\hline $\mathbf{8}$ & Nitrogen & 4.48 & 3.04 & 1.12 & 0.82 & 81.69 \\
\hline $\mathbf{9}$ & Chloride & 99.96 & 32.98 & 21.86 & 16.36 & 83.63 \\
\hline $\mathbf{1 0}$ & Sulphate & 19.05 & 7.03 & 4.48 & 2.93 & 84.61 \\
\hline $\mathbf{1 1}$ & Biomass $(\mathrm{gm} / 100 \mathrm{~mL})$ & 2.5 & 7.02 & 11.48 & 13.78 & +91.86 \\
\hline
\end{tabular}


Table.4 Dairy wastewater treatment by consortium of cyanobacterial species (Oscillatorial and Phormidium) with reduction of nutrient present in dairy wastewater

\begin{tabular}{|l|l|c|c|c|c|c|}
\hline $\begin{array}{c}\text { Sr. } \\
\text { No. }\end{array}$ & \multicolumn{1}{|c|}{ Parameters } & $\begin{array}{c}\text { Untreated dairy } \\
\text { wastewater } \\
\text { Zero Day } \\
(\mathbf{m g} / \mathbf{L})\end{array}$ & $\begin{array}{c}\mathbf{6}^{\text {th }} \mathbf{D a y} \\
\mathbf{m g} / \mathbf{L}\end{array}$ & $\begin{array}{c}\mathbf{1 2}^{\text {th }} \mathbf{D a y} \\
\mathbf{m g} / \mathbf{L}\end{array}$ & $\begin{array}{c}\mathbf{1 8}^{\text {th }} \text { Day } \\
\mathbf{m g} / \mathrm{L}\end{array}$ & $\begin{array}{c}\text { Overall } \\
\text { result } \\
\text { after 18 } \\
\text { days }(\mathbf{\%})\end{array}$ \\
\hline $\mathbf{1}$ & Colour & off white & $\begin{array}{c}\text { slight off } \\
\text { white }\end{array}$ & transparent & transparent & - \\
\hline $\mathbf{2}$ & Temperature $\left({ }^{\circ} \mathrm{C}\right)$ & 28.1 & 28.9 & 29 & 29.1 & - \\
\hline $\mathbf{3}$ & pH & 9.21 & 9.38 & 8.88 & 8.18 & 88.81 \\
\hline $\mathbf{4}$ & DO & 1.01 & 1.9 & 2.2 & 4.6 & +91.08 \\
\hline $\mathbf{5}$ & BOD & 166.11 & 22.27 & 13.65 & 3.09 & 98.13 \\
\hline $\mathbf{6}$ & COD & 96 & 18 & 12.8 & 9.8 & 89.79 \\
\hline $\mathbf{7}$ & Phosphate & 1.5 & 0.48 & 0.2 & 0.14 & 90.66 \\
\hline $\mathbf{8}$ & Nitrogen & 4.48 & 3.64 & 1.54 & 1.05 & 76.56 \\
\hline $\mathbf{9}$ & Chloride & 99.96 & 27.55 & 23.34 & 17.18 & 82.81 \\
\hline $\mathbf{1 0}$ & Sulphate & 19.05 & 7.58 & 4.85 & 3.23 & 83.04 \\
\hline $\mathbf{1 1}$ & Biomass & 2.5 & 6.13 & 12.31 & 16.01 & +99.20 \\
\hline
\end{tabular}

Table.5 Quantitative measurement of antioxidant phycobiliproteins by UV-Visible spectrophotometer in two cyanobacterial species and its consortium

\begin{tabular}{|c|l|c|c|c|} 
Sr. No. & Name of phycobiliproteins & $\begin{array}{c}\text { Oscillatorial } \\
\text { species } \\
\text { mg/L }\end{array}$ & $\begin{array}{c}\text { Phormidium } \\
\text { species } \\
\text { mg/L }\end{array}$ & $\begin{array}{c}\text { Consortium } \\
\text { species } \\
\text { Mg/L }\end{array}$ \\
\hline $\mathbf{1}$ & C-phycocyanin (C-PC) & 0.133 & 0.026 & 0.096 \\
\hline $\mathbf{2}$ & Phycoerythrin (PE) & 0.221 & 0.048 & 0.186 \\
\hline
\end{tabular}

Table.6 Lipid extraction from cyanobacterial oscillatorial and phormidium species and its consortium

\begin{tabular}{|c|l|c|c|c|}
\hline Sr. & \multicolumn{1}{|c|}{ Item } & $\begin{array}{c}\text { Oscillatorial } \\
\text { species } \mathbf{~ m g / L ~}\end{array}$ & $\begin{array}{c}\text { Phormidium } \\
\text { species } \mathbf{m g} / \mathbf{L}\end{array}$ & $\begin{array}{c}\text { Consortium } \\
\text { species } \\
\text { Mg/L }\end{array}$ \\
\hline $\mathbf{1}$ & Incubation days & 18 & 18 & 18 \\
\hline $\mathbf{2}$ & Biomass productivity $\left(\mathrm{mg} / \mathrm{l}^{-1} \mathrm{~d}^{-1}\right)$ & 788 & 765 & 945 \\
\hline $\mathbf{3}$ & Dry weight $(\mathrm{g} / \mathrm{l})$ & 1.0 & 1.0 & 1.0 \\
\hline $\mathbf{4}$ & Lipid content $\left(\mathrm{mg} / \mathrm{l}^{-1}\right)$ & 175.02 & 68.13 & 97.67 \\
\hline $\mathbf{5}$ & Average lipid productivity $\left(\mathrm{mg} / \mathrm{l}^{-1} \mathrm{~d}^{-1}\right)$ & 9.72 & 3.87 & 5.42 \\
\hline
\end{tabular}


Fig.1 Isolated species of cyanobacteria from dairy wastewater a) Oscillatorial spp. b) Phormidium spp., c) its consortium
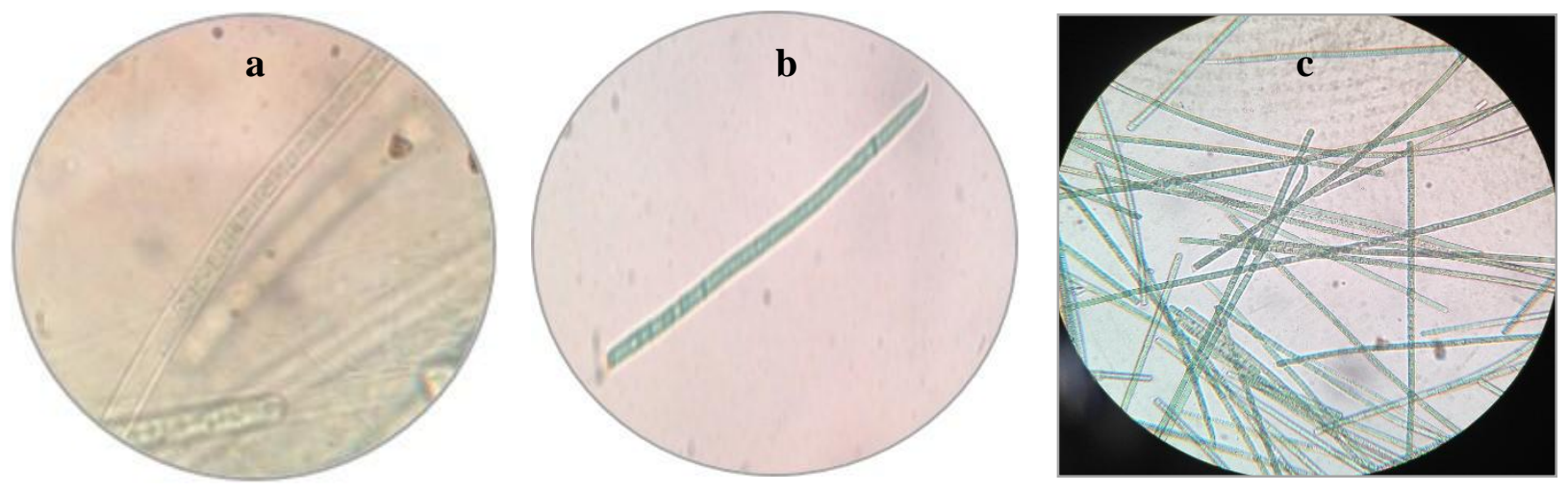

Fig.2 Physico-chemical analysis of Dairy wastewater before and after inoculation of Oscillatorial species, Phormidium species and its consortium and its biomass production
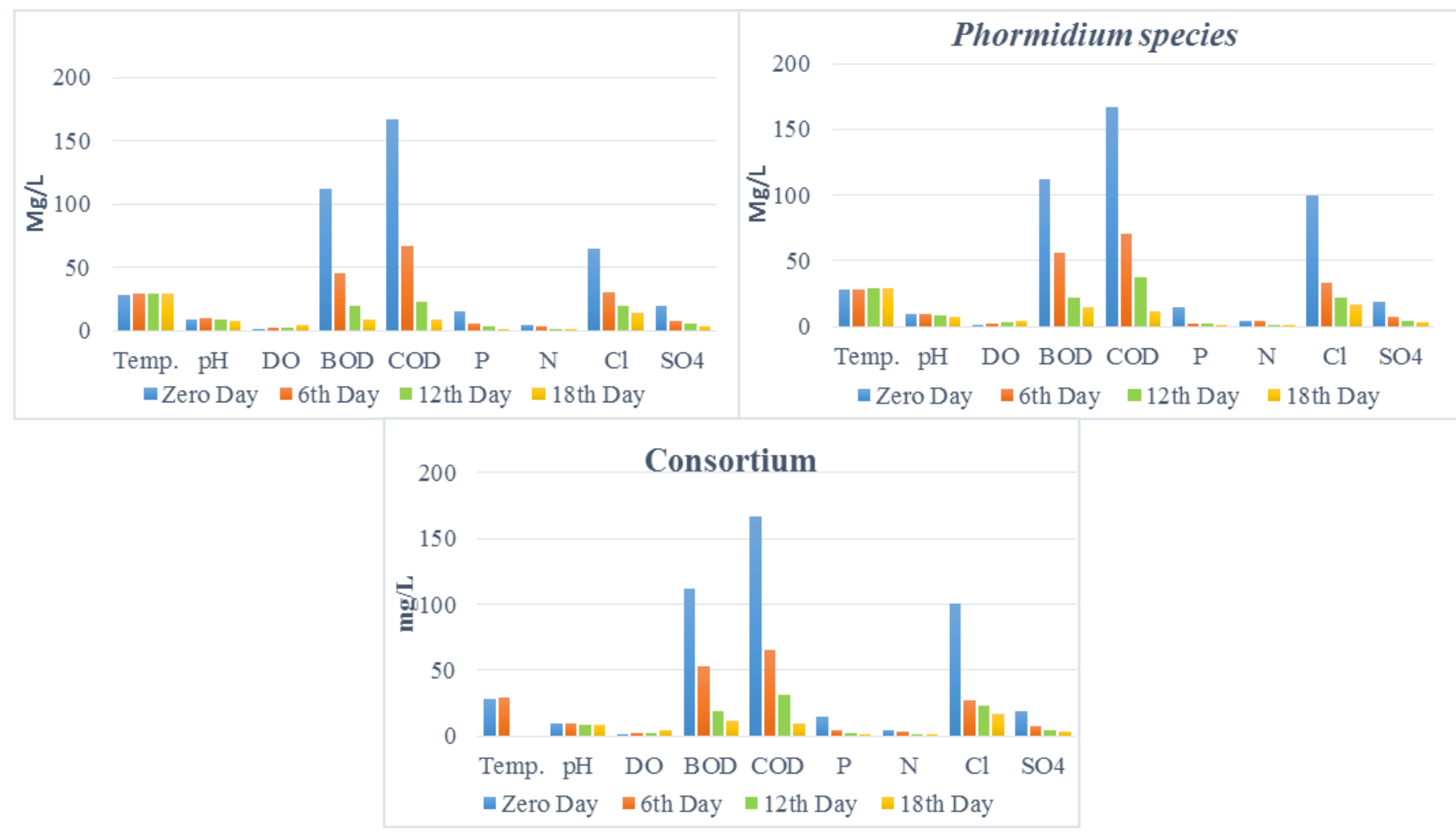
Fig.3 Cyanobacterial biomass produced after 18 days of dairy wastewater treatment

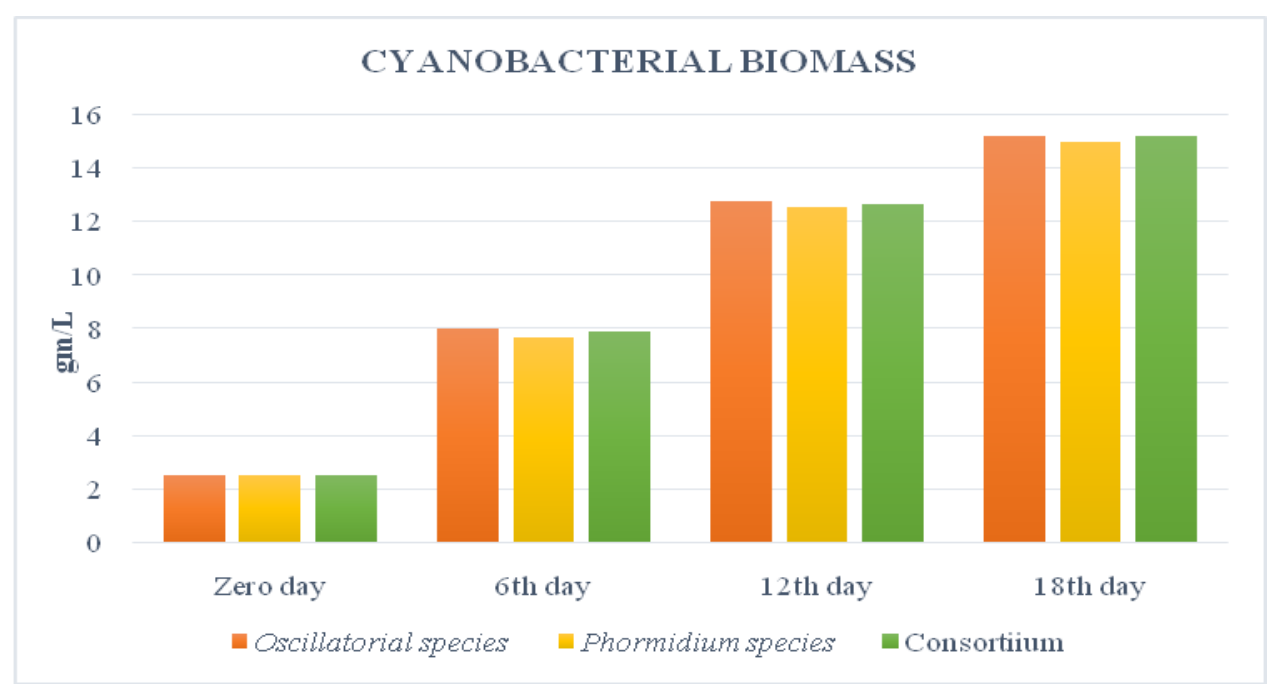

Fig.4 Phycobiliproteins production from biomass of Oscillatorial species, Phormidium species and its consortium

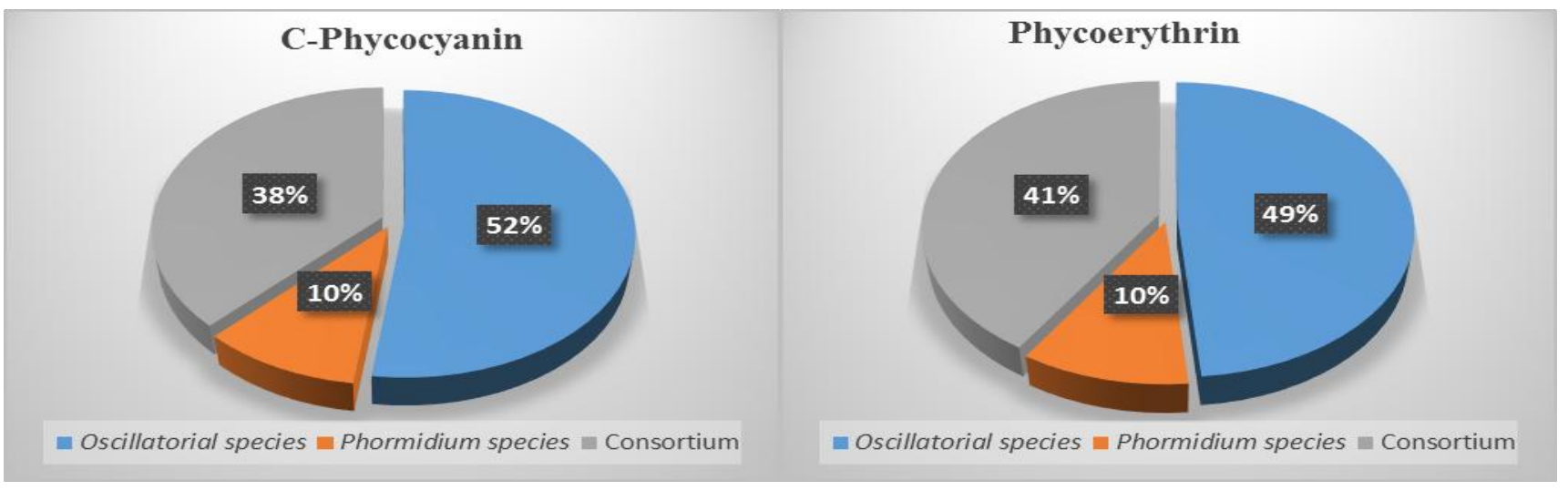

Fig.5 Absorbance spectrum pattern of phycobiliproteins extraction from Oscillatoria and Phormidium species
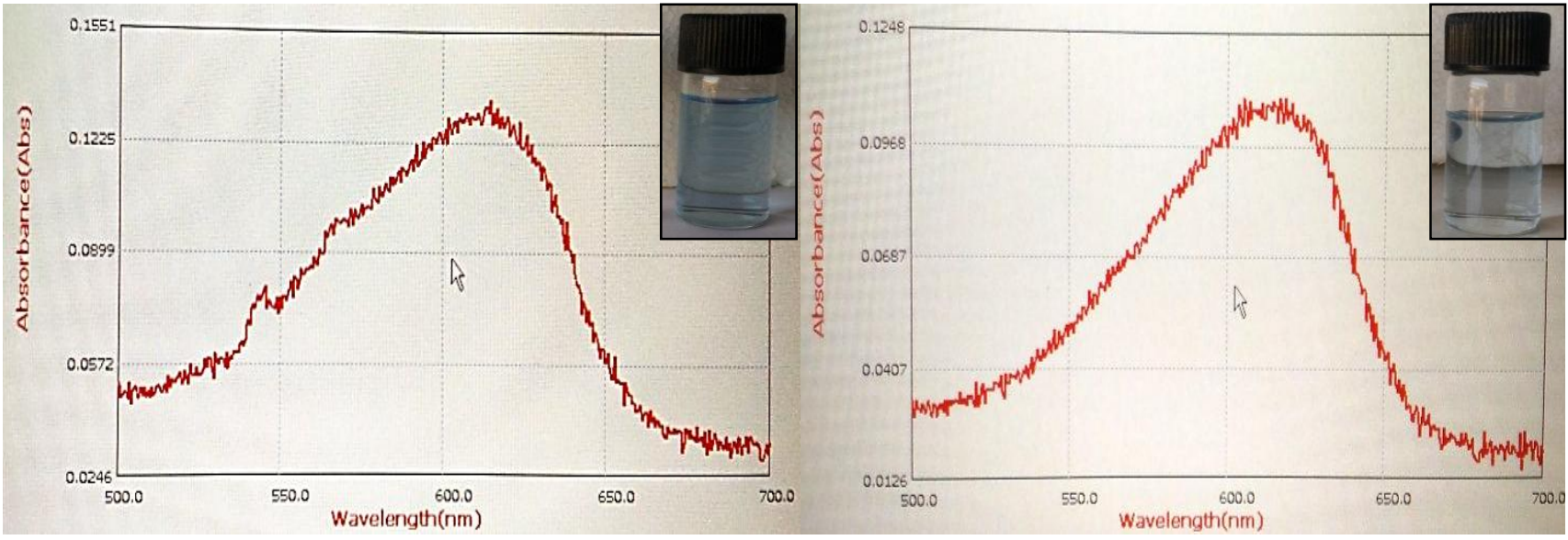
Fig.6 Lipid extraction from Oscillatorial species, Phormidium species and its consortium

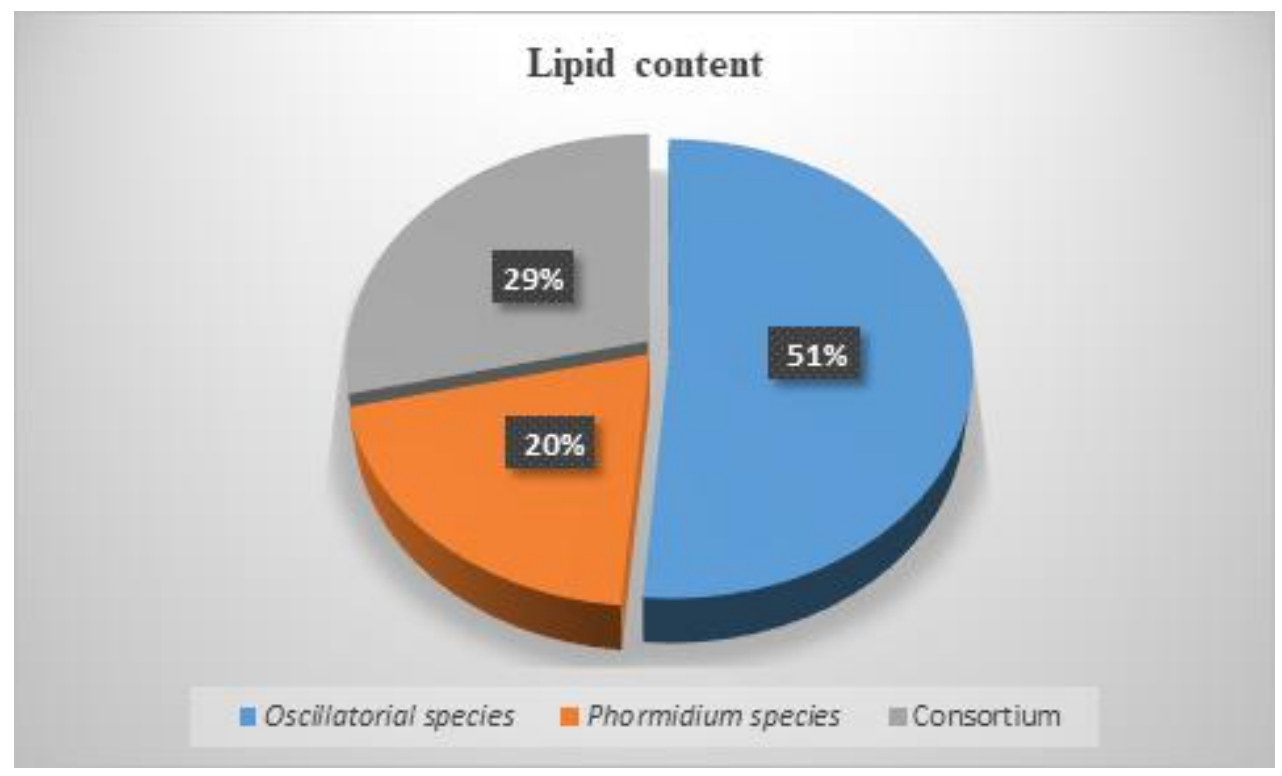

The experiment of cyanobacteria based dairy wastewater treatment and simultaneously removal of nutrients was carried out for the 18 days with untreated dairy wastewater. In this experiment, checked the presence of initial concentrations of total nutrients and examined the concentration of nutrient at the interval of every 6 day after inoculation of oscillatoria and phormidium species and its consortium in untreated dairy wastewater.

After 18 days of experiment cyanobacteria was reduced the overall nutrients upto $87.50 \%$ in untreated dairy wastewater shows in Table $2-4$. At zero day the amount of nitrogen $(\mathrm{N})$ was $4.48 \mathrm{mg} / \mathrm{L}$ and it reduced to $1.11,0.82$ and $1.05 \mathrm{mg} / \mathrm{L}$ after 18 days (Fig. 2) by oscillatorial, phormidium speciesand its consortium, respectively. The overall nitrogen reduction percentage was $75.22 \%, 81.69 \%$ and $76.56 \%$ by cyanobacterial Oscillatorial species, Phormidium species and its consortium, respectively. The initial phosphate concentration was $1.5 \mathrm{mg} / \mathrm{L}$ was reduced to $0.21,0.09$ and $0.14 \mathrm{mg} / \mathrm{L}$ after 18 days by Oscillatorial, Phormidium species and its consortium, respectively. The overall phophate reduction percentage was $86 \%, 94 \%$ and $90.66 \%$ by cyanobacterial Oscillatorial species, Phormidium species and its consortium, respectively (Fig. 2). The overall growth of the cyabacterial biomass was $94.60 \%, 91.86 \%$ and $99.20 \%$ oscillatoria, phormidium species and its consortium, respectively (Fig. 3). Similar or higher nitrient removal efficiencies were observed by other researchers for algae-based treatment. The dissolve oxygen of dairy wastewater after 18 days of treatment was increase overall $89.58 \%$. Woertz et al., 2005reported that the using algae remove $96 \%$ of nutrient present in the municipal and dairy wastewater. Our cyanobacterial species efficiency to reduce nutrient is affirmation to this.

\section{Extraction of high value compund from cyanobacterial biomass}

The amount of biomass production after dairy wastewater treatment by oscillatorial, phormidium species and its consortium was rise upto $94.60 \%, 91.86 \%$ and $97.20 \%$, respectively. Table 5 and Figure 4 shows that the extraction of pyhcobiliproteins (C-PC and $\mathrm{PE}$ ) and its quantitative measurement, the amount produced by Oscillatorial, 
Phormidium species and its consortium. Figure 5 shows the absorption spectrum pattern of the crude extract from the oscillatoria and spirulina species contain mainly C-PC (with absorption maxima at 620 $\mathrm{nm})$. Among oscillatorial, Phormidium species and its consortium, oscillatorial species produced maximum amount i.e. 0.133 $\mathrm{mg} / \mathrm{L}$ of C-PC, while phormidium species and its consortium produced $0.026 \mathrm{mg} / \mathrm{L}$ and $0.096 \mathrm{mg} / \mathrm{L}$, respectively. In case of $\mathrm{PE}$ oscillatorial species produced maximum amount i.e. $0.221 \mathrm{mg} / \mathrm{L}$, while phormidium species and its consortium contaun $0.048 \mathrm{mg} / \mathrm{L}$ and $0.206 \mathrm{mg} / \mathrm{L}$, respectively. Based on the results oscillatoria species contain maximum quantity of C-PC compare to phormidium species and its consortium, similarly same results also in case of PE. Patel et al., 2005 extract the phycobili proteins from three different cyanobacterial species with almost similar amount of production, our result is at par with this.

\section{Extraction of lipid from cyanobacterial biomass}

The lipid content from different isolated species of cyanobacteria i.e. Oscillatorial, \#phormidium species and its consortium shown in Table 6 and Figure 6. The lipid content from Oscillatorial species was about $175.02 \mathrm{mg} / \mathrm{l}^{-1}$ which was about greater than that from Phormidium species and its consortium. Table 6 shows the Oscillatorial species has highest lipid productivity i.e. 9.72 $\mathrm{mg} / \mathrm{l}^{-1} \mathrm{~d} \mathrm{mg} / \mathrm{l}^{-1}$ then Phormidium species and its consortium. Lee et al., (2010) reported the average lipid content extracted from microalgae by Bligh and Dyer's method. Our result is affirmation to this.

In this study the isolation of cyanobacteria from collected dairy wastewater samples was done and it was treated by isolated cyanobacterial species that pools nutrient removal and extraction of high value compound from generated cyanobactrial biomass. High value compounds i.e. C-PC extracted from Oscillatoria, Phormidium species and its consortium was found to be $0.133 \mathrm{mg} / \mathrm{L}, 0.026 \mathrm{mg} / \mathrm{L}$ and $0.096 \mathrm{mg} / \mathrm{L}$, respectively. This study shows the capability of cyanobacterial species for the removal of nutrients presents in dairy wastewater to produce high value compounds and can remove $94 \%$ COD as well as $87 \%$ overall nutrient of dairy wastewater very efficiently.

\section{References}

Bligh, E. G., and Dyer, W. J. 1959. A rapid method for total lipid extraction and purification. Can. J. Biochem. Physiol. 37, 911- 917.

Blok, J., De Morsier, A., and Gerike, P. 1985. Harmonisation of ready biodegradability tests. Chemosphere. 14, 1805-1820.

Elango, V., Yuvakkumar, R., Jegan, S., Kannan, N., and Rajendran, V. 2008. A simple strategy to purify Cyanobacterial cultures. Advanced Biotech. 23-24.

Ferris, M. J., and Hirsch, C. F. 1991. Method for isolation and purification of cyanobacteria. Appl. Environ. Microbiol. 57, 1448-1452.

Lee, J. Y., Chan, Y., Jun, S. Y., Ahn, C. Y., and Oh, H. M. 2010. Comparison of several methods for effective lipid extraction from microalgae. Bioresource Technology. 101, S75-S77. Lenore, S. C., Greenberg, A. E., and Eaton, A. D. 1998. Standard Methods for the Examination of Water and Wastewater. APHA 20th Edition, American Public Health Association, NW, Washington, DC.

Munawar, M. 1970a. Limnological studies on freshwater ponds of Hyderabad, India. II. The Biotype. Hydrobiologia. 35(1), 127-162 (1970a). 
Munawar, M. 1970b. Limnological studies on freshwater ponds of Hyderabad. India. II. The biocoenose-distribution of unicellular and colonial phytoplankton in polluted and unpolluted environments. Hydrobiologia. 36(1), $105-128$.

Nancy, S. and Mai-Linh, H. 2011.Algae Identification lab guide. Agriculture and Agri-Food Canada Agri-Environment Services Branch.

Oswald, W. J. 2003. My sixty years in applied algology. J. Appl. Phycol. 99-106.

Patel, A., Mishra, S., Pawar, R., and Ghosh, P. K. 2005. Purification and characterization of C-Phycocyanin from cyanobacterial species of marine and freshwater habitat. Protein Expr. Purif. $40,248-255$.

Pathade, K. N. 2012. Cyanobacterial diversity in dairy wastewater. Multi. Sci. Intl. Ref. \& Ind. Quar. J. 2(2), 54-57.

Sara, P. C., Iris A. H., Diana L. C., Nancy, O. S., Miguel A., Romero, O., and Roberto
P., S. 2015. Extraction and purification of high-value metabolites from microalgae: essential lipids, astaxanthin and phycobiliproteins. Micro. Biotech. 8(2), 190-209.

Trivedy, R. K. and Goel, P. K. 1984. Chemical and Biological Methods for Water Pollution Studies. Environmental Publication, Karad.

Uslu, L., Isik, O., Koc, K., and Goksan, T. 2011. The effects of nitrogen deficiencies on the lipid and protein contents of Arthrospira platensis, Afr. J. Biotechnol. 10, 386-389.

Vourch, M., Balannec, B., Chaufer, B., and Dorange, G. 2008. Treatment of dairy industry wastewater by reverse osmosis for water reuse. Desalination. 219, 190202.

Woertz, A., Feffer, T., Lundquist and Nelson, Y. 2005. Algae grown on dairy and municipal wastewater for simultaneous nutrient removal and lipid production for biofuel feedstock. Ph.D. Thesis.

\section{How to cite this article:}

Jayesh H. Kabariya and Vimal M. Ramani. 2018. Dairy Wastewater Treatment by Cyanobacteria for Removal of Nutrients with Extraction of High Value Compounds from Biomass. Int.J.Curr.Microbiol.App.Sci. 7(04): 1527-1538. doi: https://doi.org/10.20546/ijcmas.2018.704.172 